\title{
Az egészségügyi rendszerek rezilienciája: elméleti keretek, gyakorlati megfontolások
}

\author{
Resilience of health systems: theoretical framework, practical considerations
}

\author{
Farkas Borbás Fanni ${ }^{1}$ Dr. Gresz Miklós ${ }^{1}$ \\ ${ }^{1}$ Országos Kórházi Főigazgatóság, Budapest
}

Nemzeti és nemzetközi szinten is foglalkoztatja a szakértőket, hogy hogyan lehetséges az ellátórendszert talpra álítani egy, a rendszer müködését megzavaró sokk után, milyen mérési módszerek, indikátorok segíthetik a folyamat pontos megismerését, esetleg hogyan lehetne felkészülni és elöre jelezni egy újabb vészhelyzetet. A reziliencia kérdése a 2009-es gazdasági válság idején került fókuszba, azóta folyamatos érdeklődés tárgya, a koronavírus pandémia pedig kifejezetten aktuálissá teszi. Cikkünk célja az egészségügyi rendszerek rezilienciájával foglalkozó fő irodalmak áttekintése, a fogalom definiálása, a reziliens ellátórendszer ismérveinek, valamint az ezt erősítő és a vészhelyzetet leküzdő stratégiáknak a bemutatása. A reziliens egészségügyi rendszer úgy tud szembenézni különféle megrázkódtatásokkal, szerkezeti változásokkal, hogy nem veszíti el azt a képességét, hogy fenntartható módon a társadalom jóllétét szolgálja. A reziliencia képessége az egész egészségügy rendszer tulajdonsága, nem pedig egyetlen dimenziója. Az egészségügyi rendszer általános megerösítése sokat tesz a sokkokkal szembeni felkészülés érdekében. Az azonosított gyenge területek speciális fejlesztése pedig nemcsak a rendszer rezilienciáját, hanem a teljesítményét is javíthatja. A felkészültség önmagában még nem garantálja az alkalmazkodóképességet, ezért a sokk-kezelési stratégiák megléte szintén kritikus fontosságú. A bemutatott irodalmak több olyan stratégiát azonosítanak, amelyek segíthetik a rendszer alkalmazkodóképességének fejlesztését. Ezeket a magyar ellátórendszer erősítéséhez is ajánljuk.

At the national and international level, experts are interested in how it is possible to recover the health care system after a shock that is disturbing the operation of the system, what measurement methods and indicators can help to get an accurate understanding of the process, and how to prepare for and predict the following emergency situation. The issue of resilience has come into focus during the economic crisis in 2009 and has been the subject of constant interest since then, and the coronavirus pandemic makes it particularly relevant. The aim of this publication is to give a review of the main literature on the resilience of health systems, the definition of the concept, the presentation of the criteria of the resilient care system, and the strategies to strengthen it and overcome shocks. The resilient health care system can face various shocks and structural changes without losing its ability to serve the well-being of society in a sustainable way. The ability to resilience is a characteristic of the entire health care system, not a single dimension. The general strengthening of the health system means a lot to prepare for shocks. The special improvements to the identified weak areas can improve not only system resilience but also performance. Preparedness alone does not guarantee resilience, so the existence of shock management strategies is also critical. The literature presented identifies several strategies that can help improve the resilience of the system. We also recommend these to strengthen the Hungarian health care system.

\section{BEVEZETÉS}

A súlyos akut légúti tünetegyüttest okozó (sudden acut repiratory syndrome-2, SARS-2) koronavírus járvány (coronavirus disease 2019 pandemic továbbiakban: COVID-19 járvány) kitörése középpontba helyezte az egészségügyi rendszerek alkalmazkodóképességének kérdését. Publikációnkban bemutatjuk, hogy mit érthetünk az egészségügyi rendszer rezilienciája alatt, hogyan lehet ezt a tulajdonságot fejleszteni, erősíteni a rendszer egyéb céljai mellett (pl.: minőség, hatékonyság), hogy miért fontos mindezzel ágazati stratégiai szinten is foglalkozni, hogyan lehet felkészültté tenni az ellátórendszert. Cikkünkben a reziliencia mérésére is kitérünk, amely kézzelfogható segítséget jelenthet az ellátórendszer alkalmazkodóképességének teszteléséhez.

A rezilienciára nincs pontos magyar nyelvű kifejezés, ami megnehezíti a fogalom helyes értelmezését. Ez idáig leggyakrabban „ellenálló képességnek” fordították és „a természeti és humán eredetủ káros behatásokkal, változásokkal szembeni tűrőképesség, helyreállási képesség" definíciójaként, pozitív értelemben használták [1]. Az ellenállás esetén a külső behatás nem feltétlenül hagy nyomot a rendszeren, sőt a rendszer maga is mintegy megelőző csapást mérhet rá, felkészülhet a „támadásra”, míg a reziliencia esetében mindenképpen történik kedvezőtlen változás, csak a rendszer képes a támadást túlélni, tud regenerálódni és képes akár a saját hasznára fordítani a történéseket. A rendszernek ahhoz, hogy elmondhassuk róla, hogy reziliens, vissza kell térnie, vissza kell pattannia (bounce back) egy új egyensúlyi ponthoz. A rezilienciát magyar nyelven legpontosabban az alkalmazkodóképesség vagy a megküzdőképesség szavakkal írhatjuk 
le $[1,2]$. A reziliencia fogalma nemcsak rendszer szinten, hanem az egyén szintjén is értelmezhető, régóta használt fogalom a pszichológiában. Jelen cikkünk a rendszerszintű megközelítést veszi górcső alá.

\section{MÓDSZER}

A szerzők tagjai az Európai Bizottság Egészségügyi Rendszerek Teljesítményértékelési Munkacsoportjának (Expert Group on Health System Performance Assessment, továbbiakban: Munkacsoport), amely hónapok óta foglalkozik ezzel a kérdéssel [2]. A téma körüljárása érdekében kiegészítő irodalomkutatást végeztünk, amelyhez a Google Scholar és a Pubmed keresőjét használtuk. Ezenfelül megvizsgáltuk a fontosabb nemzetközi szervezetek (OECD, WHO, EU) weboldalait. Csak olyan publikációkat válogattunk be, amelyek az egészségügyi rendszer rezilienciájának koncepciójával, elvi kereteivel foglalkoznak. Keresőszóként alapfeltételként szabtuk meg, hogy az 'egészségügyi rendszer' (health system) szerepeljen a cikkben, ehhez pedig kísérőszónak a 'rezilienciát' (resilience) és 'helyreállítás' (recovery) szavakat használtuk.

\section{EREDMÉNYEK}

\section{Mit értünk az egészségügyi rendszer rezilienciája alatt?}

Az egészségügyi rendszer rezilienciááat úgy lehet meghatározni, mint az egészségügyi szereplők, intézmények és a lakosság képességét a válságokra való felkészülésre és az azokkal szembeni hatékony reagálásra; amely során fennmaradnak az alapvető funkciók, és a helyzet során megtanult tapasztalatok alapján van lehetőség újjászervezésére, ha a körülmények úgy kívánják [3]. A szakirodalom meglehetősen széleskörűen értelmezi a reziliencia fogalmát.

2017-ben az Európai Bizottság Közös Kutatási Központja (European Commission's Joint Research Centre) publikálta az első uniós szintű koncepcionális keretrendszerét a rezilienciáról, ahol a reziliens rendszert (vagy társadalmat) úgy definiálták, hogy az úgy tud szembenézni különféle megrázkódtatásokkal, tartós szerkezeti változásokkal, hogy nem veszíti el azt a képességét, hogy fenntartható módon a társadalom jóllétét szolgálja (vagyis biztosítsa a mostani társadalom jóllétét anélkül, hogy a jövő generációiét veszélyeztetné) $[4,5]$.

Az Európai Bizottság Egészségügyi Rendszer Teljesítményértékelési Munkacsoportja az elmúlt években behatóan foglalkozott a témával és kísérletet tett a reziliencia definíciójának pontos meghatározására:

„Az egészségügyi rendszer rezilienciája a rendszer azon képességét írja le, hogy a) proaktívan előre jelzi, b) elnyeli és c) alkalmazkodik a sokkokhoz és a szerkezeti változásokhoz biztosítva (1) a szükséges működés fenntartását, (2) az optimális teljesítmény lehető leggyorsabb folytatását, (3) a szerkezet és a funkciók átalakítását a rendszer megerősítése érdekében, és (esetleg) (4) csökkentse a jövőbeli hasonló sokkokkal és szerkezeti változásokkal szembeni sebezhetőségét." [2]

A Munkacsoport meghatározása Blanchet és munkatársai definícióján alapul, amely három alapvető típusát határozza meg a rezilienciának [6]:

- abszorpciós (enyhíteni a sokk hatásait, és azonos szintű erőforrások és kapacitások felhasználásával továbbra is ugyanolyan szintű szolgáltatást nyújtani)

- adaptív (a sokk által kiváltott rendkívüli körülmények ellenére a rendszer képes a szükséges műveletek fenntartására eltérő erőforrások mellett) és

- transzformációs (a rendszer képes átalakítani a struktúráját és működését reagálva a változásokra) [7].

Ez kiegészül egy új típussal a preventív rezilienciával, ami az egészségügyi rendszer azon képessége, hogy proaktívan előre tudja előre jelezni a sokkot, és megteremti a szükséges feltételeket a sokk hatásainak a minimalizáláshoz [2].

\section{Potenciális veszélyforrások, sokkok, amelyek hatással lehetnek az egészségügyi rendszerre}

A stresszorok, sokkok sokféle kategóriába sorolhatók pl.: természetük szerint, súlyosságukat, időtartamukat és gyakoriságukat tekintve. Különösen fontos annak a megkülönböztetése, hogy akut sokkról (hirtelen kialakult helyzet, ami rövid ideig áll fent) vagy krónikus stresszorok jelenlétéről (hosszan elhúzódó, sokáig fennálló helyzet, amely szisztematikusan befolyásolja az egészségügyi rendszer működését) beszélünk [2]. A sokk kiszámíthatatlan akut inger, amely azonnali reagálást igényel, míg a strukturális változások inkább a rendszert fenyegető krónikus stresszorok jelenlétére utalnak, például képzett szakemberek hiányára vagy a népesség elöregedésére [7]. Jellegük szerint pedig megkülönböztethetünk járványügyi, gazdasági, technológiai, környezeti, társadalmi, politikai és geopolitikai hatásokat. Azt is fontos kiemelni, hogy egy-egy sokk jelenléte kihatással van több területre, rendszerre is, és a rá adott válasz nagyban függ az adott sokk időtartamától vagy több sokkhatás egyidejű jelenlététől.

\begin{tabular}{|l|l|l|}
\hline & Akut & Krónikus \\
\hline Járványūgyi & Ebola, COVID19 & oltásmegtagadás \\
\hline Gazdasági & Kōltségvetési megszoritás & $\begin{array}{l}\text { gazdasági válság, munkanélküliség, } \\
\text { munkaeröhiány, elvándorlás }\end{array}$ \\
\hline Technológiai & Kibertámadás, havaria & $\begin{array}{l}\text { Információs és orvosi rendszerek, } \\
\text { eszközök elavultsága }\end{array}$ \\
\hline Kōrnyezeti & Arviz, fōldrengés & Légszennyezettség, Klimaváltozás \\
\hline Társadalmi & Rendszerreformok & Migráció, egészségtudatosság hiánya \\
\hline Politikai & $\begin{array}{l}\text { Jogszabályváltozás, } \\
\text { Kormányváltás }\end{array}$ & $\begin{array}{l}\text { A múködést elōsegitö jogszabályok } \\
\text { megalkotásának hiánya }\end{array}$ \\
\hline Geopolitikai & Terrortámadás & Háborús konfliktus \\
\hline
\end{tabular}

1. táblázat

Az egészségügyi rendszereket érö stresszorok és sokkok típus szerint, példákkal szemléltetve. Forrás: saját gyújtés 


\section{Stratégiák}

Kruk és munkatársai [3] kiemelik, hogy az egészségügyi ellátórendszerek összetett adaptív rendszerek, és a reziliencia képessége az egész egészségügyi rendszernek a tulajdonsága, nem pedig egyetlen dimenziója. A reziliencia építése tehát kontextustól függ és ismétlődő, ehhez előzetesen fel kell mérni a rendszer kapacitásait és gyengeségeit,el kell indítani a rendszer sebezhető elemeibe történő beruházásokat még a válság kialakulása előtt, ezeket meg kell erősíteni a vészhelyzet során és el kell végezni a teljesítmény felülvizsgálatát a válság utáni időszakban. A jogszabályoknak elő kell segíteniük a gyors reakciót, biztosítani kell a megfelelő hatáskört a vészhelyzetben fellépő szervek, hatóságok számára, valamint ki kell térniük a közfinanszírozott és magánfinanszírozott ellátók szerepére és felelősségére, ezzel lehetővé téve a rugalmasságot az erőforrások megosztására az egész egészségügyi rendszerben. A válság végén az adaptív egészségügyi rendszer nemcsak másképpen, hanem jobban működik. A reziliens egészségügyi rendszer észleli (aware) a rendelkezésére álló humán, fizikai és információs eszközöket és gazdasági lehetőségeket [4].

Hanefeld és munkatársai [8] kidolgoztak az áttekintett irodalmak tapasztalatai alapján egy „3+2” modellt, amely három egészségügyi rendszerfunkciót - egészségügyi információs rendszereket, finanszírozást / finanszírozási mechanizmusokat és az egészségügyi munkaerőt tartalmaz. Mindhárom dimenziót két horizontális szempont alakítja: a „kormányzás”, mint alapvető funkció, amely befolyásolja az összes rendszerdimenzió működését; és az uralkodó „értékek és meggyőződések”, amelyek meghatározzák a sokkokra adott választ, és hogy ez a válasz hogyan alakul ki egyéni és közösségi szinten. Kiemelik, hogy az egészségügyi információs rendszereket fontos összekötni más ágazatok információs rendszereivel. Például ez az éghajlatváltozás esetében azt jelenti, hogy a rutin egészségügyi adatok gyűjtésébe integrálni kell a szélsőséges időjárási események és azok káros egészségügyi következményeinek elörejelzését, valamint a hőmérsékleti változások, viharok, árvizek eredményeként a betegségökológia és a betegségminták hosszabb távú változásainak tervezését. Ezt segíthetik a nemzeti egészségügyi számlák és a megfelelő népességi és egészségi állapotot vizsgáló indikátorok nyomon követése.

$A z$ is megfigyelhetö, hogy az egyenlötlenségek gyakran növekednek a sokkok során, valamint utánuk, ez az egyenlőtlenség érezhető az egészségi állapotban, a közvetlen egészségügyi kifizetésekben vagy a rendszerhez való hozzáférésben. Ezeket enyhíteni kell, és figyelembe kell venni ezen tényezőket a reziliencia kialakítását, erősítését célzó politikákban [9.] A kormányzat szerepét Fridell és munkatársai [10] is kiemelik: a kormányzati fellépés kritikus szerepet játszik a sokkokra adott válaszok végrehajtásában és összehangolásában, és ez jelentősen befolyásolja a rendszerek alkalmazkodóképességét és a válság egészségügyi hatásait. Alternatívaként felmerülhet az egészségügyi rendszer irányításának policentrikussá tétele, ez enyhítheti bizonyos sokkok terjedését, illetve segítheti a reziliencia előmozdítását. A bizonytalan sokkok megelőzését segítheti a helyi kormányzás megerősítése és az erős közösségi részvétel [10] .A felkészült, reziliens egészségügyi rendszer a megfelelő, jó kormányzás eredménye. A jó kormányzás aspektusai között pedig az elszámoltathatóság, a transzparencia, a részvétel, az integritás és a politikai kapacitások fokozása szerepel [11].

Finanszírozási szempontból a reziliens egészségügyi rendszert nemzetileg finanszírozzák, lehetőleg adókon keresztül, de emellett szükséges a betegek általi közvetlen egészségügyi kifizetések (out-of-pocket) összegének csökkentése az egészségügyi szolgáltatások megfizethetőségének érdekében, valamint az egyenlőtlenségek minimalizálása az egészségügyi költségek miatti elszegényedés elleni védelem érdekében [10].

A stratégiai válasz jellegét a sokk típusa és súlyossága határozza meg. Ezt tovább befolyásolja az a sokkciklus, amelyben az egészségügyi rendszer áll. Thomas és munkatársai négy különálló szakaszt különböztetnek meg [12]:

1. szakasz: Felkészültség (Preparedness), amely azzal függ össze, hogy a rendszer mennyire érzékeny a különféle zavarokra;

2. szakasz: Sokk kezdete és riasztás (Shock onset and alert), ahol a hangsúly a sokk kezdetének és típusának időben történő azonosítására van;

3. szakasz: Sokkhatás és kezelés (Shock impact and management), amikor a rendszer reagál a sokkra, és szükség esetén alkalmazkodik vagy átalakul annak biztosítása érdekében, hogy az egészségügyi rendszer céljait továbbra is elérjék;

4. szakasz: Felépülés és tanulás (Recovery and learning), amikor visszatér valamilyen szinten a normálishoz, de a sokk következményeként változások következhetnek be [12].

Összefoglaló tanulmányukban 4 területre bontva 13 rezilienciát erősítő stratégiát emelnek ki pl.: humán és fizikai erőforrások megfelelő szintje és elosztása, motivált és jól ösztönzött munkaerő, hatékony információs rendszerek és információáramlás, hatékony és részvételen alapuló vezetés, elegendő pénzügyi forrás biztosítása és azok rugalmassága, szükség esetén extra források bevonása stb. Kiemelik, hogy az egészségügyi rendszer általános megerősítése elősegíti a sokkokra való jobb felkészülést a reziliencia érdekében. Az azonosított gyenge területek speciális fejlesztése pedig nemcsak az rendszer rezilienciáját, hanem egészségügyi rendszer egészének teljesítményét is javíthatja [12].

\section{Variációk sokkhatásokra, az alkalmazkodóképesség megjelenése és az egészségügyi rendszer teljesítményének változásai}

Az alábbiakban a Munkacsoport ábráját felhasználva szemléltetjük, hogy a sokkot átélő egészségügyi rendszer 
hogyan képes az alkalmazkodóképességét az idő múlásával igazolni, lásd 1. ábra.

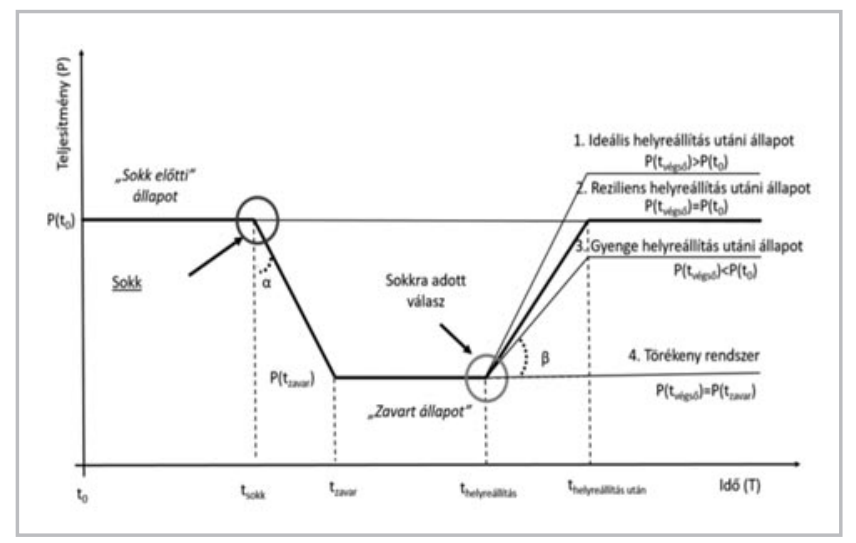

1. ábra

Az egészségügyi rendszer teljesítményének változása egy sokk hatásra, Forrás: EU Expert Group on Health Systems Performance Assessment (HSPA), 2020, 8. oldal [2]

Az idő múlásával az egészségügyi rendszer teljesítménye $(P)$ két fő esemény eredményeként (a sokk és az arra adott válasz) háromféle állapotba kerül: a sokk előtti állapot $P\left(t_{0}\right)$, a zavart állapot $P\left(t_{\text {zavar }}\right)$ és a helyreállítás utáni állapot

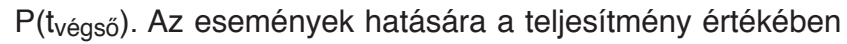
eltolódás történik, először $\mathrm{Pt}_{0}$-ról $\mathrm{Pt}_{\text {zavar-ra, ami egy csökke- }}$ nés, majd innen egy visszapattanás látható a $\mathrm{P}\left(\mathrm{t}_{\text {zavar }}\right)$-ról a

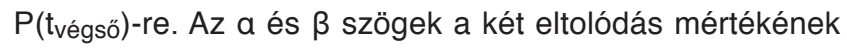
mérőszámai [2].

Ez alapján a rendszer rezilienciája az alábbi képlettel írható le [2]:

Reziliens egészségügyi rendszer ER( $(t)=\frac{\text { a visszapattanást követően nyert } P}{\text { a sokk eredményeként elveszett } P}$

A visszapattanást követően pedig négyféle kimenetről beszélhetünk:

- Hiper-reziliens: $(E R(t)>1)$, ha $P\left(t_{\text {végsö }}\right)>P(t 0)$, azaz, ha a visszanyerés nagyobb, mint a sokk által okozott veszteség, azaz a rendszer a kiindulásnál magasabb szintre tér vissza;

- Reziliens: $(E R(t)=1)$, ha $P_{(\text {tvégső })}=P\left(t_{0}\right)$, vagyis, ha a visszanyerés megegyezik a sokk által okozott veszteséggel, és a rendszer kiinduló állapotába tér vissza;

- Részlegesen reziliens: $(0<E R(t)<1)$, ha $P\left(t_{z a v a r}\right)<$ $\mathrm{P}\left(\mathrm{t}_{\text {végső }}\right)<\mathrm{P}\left(\mathrm{t}_{0}\right)$, azaz ha a visszapattanás nem arányos a sokk által okozott veszteséggel, azaz a rendszer a kiindulásnál alacsonyabb szintre tér vissza;

- Törékeny: $(E R(t)=0)$, ha $P\left(t_{\text {végsö }}\right)=P\left(t_{\text {zavar }}\right)$, azaz, ha a sokk után nem következik be helyreállás (visszapattanás), és a rendszer a sokk által eredményezett szinten marad [2].

A cél tehát az lenne, hogy az összeomlás mélysége a lehető legkisebb legyen, a rendszer hatékonyan és időben tudja módosítani a szolgáltatásait, hogy a „zavart állapot” a lehető legrövidebb ideig tartson [2].

\section{Az egészségügyi rendszer alkalmazkodóképességének monitorozása}

Szinte minden ország alkalmaz valamilyen információs rendszert az egészségügyben történő változások monitorozására, azonban az akut válság esetén szükséges információ nem mindig felel meg a normál müködési célok és rutinmenedzsment idején szükségeseknek. Mivel a rendszer nem tud minden helyzetre felkészülni és tartalékolni, így elengedhetetlen egy olyan eszköz, amely hatékonyan és rugalmasan képes felhasználni a különféle információforrásokat, felmérni az egészségügyi rendszeren kívüli szélesebb társadalmi események következményeit, amelyeket elemezve támogatni tudja az operatív döntéseket [18].

Ebben az értelemben az átfogó, pontosabb értékelési eszközök fejlesztésébe történő befektetés nemcsak instrumentális értéket képvisel a döntéshozatal szempontjából, hanem az elszámoltathatóságot segítő eszközként is szolgál annak biztosítására, hogy a rezilienciára való törekvés hoszszú távú, stabil szakpolitikai és beruházási prioritássá váljon [2].

\section{Mérési módszerek}

Alapvető kérdés, hogy honnan lehet tudni, sokk érte az egészségügyi rendszert? Milyen gyors, és mekkora a teljesítménycsökkenés? Vannak egyértelmű sokkok, amelyekre gyors válaszok születnek pl.: járványok vagy környezeti

\begin{tabular}{|c|c|c|}
\hline Jellemzök & Célok & Mérési területek (példák) \\
\hline $\begin{array}{l}\text { Felkészūlt } \\
\text { (Aware) }\end{array}$ & $\begin{array}{l}\text { 1. Az egészségũgyi rendszer } \\
\text { kapacitásainak ismerete } \\
\text { 2. A lakosság és az öket } \\
\text { fenyegetö kockázatok } \\
\text { ismerete } \\
\text { 3. Kommunikáció }\end{array}$ & $\begin{array}{l}\text { 1. Kapacitás térképek, erōforrás regiszterek } \\
\text { 2. Az ellátások igénybevételének trendjei } \\
\text { 3. A lakosság demográfiai és epidemiológiai } \\
\text { sajátosságainak vizsgálata } \\
\text { 4. A döntéshozók listája a kulcsfontosságú } \\
\text { ágazatokban } \\
\text { 5. Müködó, nyitott környezet az idöben tōrténô } \\
\text { kommunikációhoz (forródrót-szolgálatok, } \\
\text { kōzōsségi média stb.) }\end{array}$ \\
\hline $\begin{array}{l}\text { Változatos } \\
\text { (Diverse) }\end{array}$ & $\begin{array}{l}\text { Hatékony válasz a } \\
\text { külōnbözö egészségügyi } \\
\text { szükségletekre } \\
\text { - Megfelelō } \\
\text { rendszerfinanszirozás }\end{array}$ & $\begin{array}{l}\text { 6. Az alapellátásban elérhetô ellátások pontos } \\
\text { meghatározása } \\
\text { 7. A finanszirozás megfelelösége }\end{array}$ \\
\hline $\begin{array}{l}\text { Onszabá- } \\
\text { lyozás(Self } \\
\text { regulating) }\end{array}$ & $\begin{array}{l}\text { 1. A fenyegetés elszigetelése és } \\
\text { az alapvetố funkció } \\
\text { fenntartása } \\
\text { 2. Külsô erōforrảsok } \\
\text { kiaknázása }\end{array}$ & $\begin{array}{l}\text { 1. Megállapodások nem állami szolgáltatókkal } \\
\text { 2. A szolgáltatásnyújtási alternativák adatbázisa } \\
\text { az érintett és a nem érintett lakosság számára } \\
\text { 3. Együttmükődési megállapodások regionális } \\
\text { és globális szereplökkel } \\
\text { 4. Az időlegesen felfúggeszthetō ellátások } \\
\text { tervezése }\end{array}$ \\
\hline $\begin{array}{l}\text { Integrálás } \\
\text { (Integrated) }\end{array}$ & $\begin{array}{l}\text { Koordináció a nem } \\
\text { egészségügyi szereplökkel } \\
\text { (rendōrség, oktatás, } \\
\text { közlekedés stb.) } \\
\text { A lakosság bevonás a } \\
\text { bizalomépitésbe } \\
\text { Az alapellátás és a } \\
\text { szakellátás koordinációja } \\
\text { Az egészségügyi ellátás } \\
\text { összekapcsolása a } \\
\text { kôzegészségúggyel }\end{array}$ & $\begin{array}{l}\text { 5. A kész koordinációs rendszerek, vészhelyzeti } \\
\text { tervek segitik a gyors döntéshozatalt és } \\
\text { végrehajtást } \\
\text { 6. Társadalomtudományi szakemberek } \\
\text { együttmüködése egészségügyi } \\
\text { szolgáltatókkal } \\
\text { 7. A lakossággal folytatott párbeszéd } \\
\text { platformjai } \\
\text { 8. Beutalási protokollok és szabályok rōgzitése } \\
\text { 9. Surveillance és monitoring rendszerek } \\
\text { müködtetése }\end{array}$ \\
\hline $\begin{array}{l}\text { Alkalmaz- } \\
\text { kodó } \\
\text { (Adaptive) }\end{array}$ & $\begin{array}{l}\text { 1. A források átcsoportositása } \\
\text { lehetốsége a felmerülö } \\
\text { szükségletek kielégitésére } \\
\text { 2. A gyors helyi dōntéshozatal } \\
\text { elōmozditása } \\
\text { 3. Értékelés }\end{array}$ & $\begin{array}{l}\text { 1. Elöirások a források vészhelyzetben tơrténō } \\
\text { újraelosztására } \\
\text { 2. A válság elötti megállapodások, amelyek } \\
\text { lehetốvé teszik a helyi döntéshozatalt } \\
\text { válságban } \\
\text { 3. Az egészségūgyi rendszerek } \\
\text { teljesitményének értékelése válsághelyzetben } \\
\text { és nyugodt időben }\end{array}$ \\
\hline
\end{tabular}

2. táblázat

Reziliencia index. Forrás: [4] 
katasztrófák, ugyanakkor a humán erőforrás hiánya vagy a csökkenő források, a fejlesztések hiánya hosszabb távon érzékeltetik a hatásukat.

Kurk és munkatársai egy listát állítottak össze arról, hogy milyen mutatókkal lehet mérni az egészségügyi rendszer rezilienciáját. Az index nem ír elő konkrét indikátort vagy nemzeti referenciaértéket az egészségügyi rendszerek heterogenitása miatt. Öt meghatározó jellemző szerint csoportosítja a mérési területeket, ezt mutatja be a 2. táblázat [3]:

Az Egészségügyi Rendszerek és Szakpolitikák Európai Megfigyelöközpontja (European Observatory on Health Systems and Policies) és az EU HSPA által vezetett Fókuszcsoport eredménye alapján, amelyben 17 tagállam vett részt, olyan mutatókat emeltek ki, mint a kapacitás méréséhez kapcsolódó indikátorok (például ágyszám, az ágykihasználtság, ellátásra való várakozási idő, a sürgősségi infrastruktúra rendelkezésre állása), az erőforrások mobilizálását / újraelosztását vizsgáló (fizikai, emberi és pénzügyi) és az ellátási láncok megfelelőségével kapcsolatos mutatók. Egyetértettek abban, hogy a meglévő kapacitás kulcsfontosságú annak meghatározásához, hogy az egészségügyi rendszer képes-e elviselni a sokk hatásait. Problémaként merült fel a megbeszélések során, hogy bármilyen indikátor kerül is kidolgozásra és folyamatos vizsgálatra, meg kell határozni, hogy annak milyen jellegű változása jelent sokkhatást. Amennyiben krónikus sokkról van szó, a változások hónapok vagy évek alatt következnek be, szinte észrevehetetlenül. Nagy jelentősége van ilyenkor a sokk felismerésében az előzetesen rögzített küszöbértékeknek [2].

Az egészségügyi rendszerek teljesítményértékelése több országban bevett gyakorlat, az ebben foglalt indikátorok képet adhatnak a rendszer teljesítményének változásairól, segíthetnek azonosítani a gyengeségeket. Érdemes megvizsgálni azt, hogy az alkalmazkodóképesség leírására mennyire alkalmasak, hogyan lehet bővíteni, illetve az ebben foglalt eredményeket miként lehetne felhasználni a rendszer rezilienciájának értékeléséhez.

A Munkacsoport új eszközként azonosította az egészségügyi rendszerek alkalmazkodóképességének tesztelését, amely a bankszektor stressztesztjeinek tapasztalataira épít. A teszt azt méri fel, hogy a negatív események hatására a rendszer mennyire képes fenntartani a működését. $A$ teszt elvégzése tagállami hatáskör, de az értékelésben (ahogy a bankszektor esetében is) nemzetközi szervezetek, más tagállamok is közreműködhetnek, az eredményekből pedig tanulhatnak. A teszt kvantitatív és kvalitatív adatokkal is dolgozik, amelyet minden ország maga jelöl ki a kockázatok függvényében. A folyamat maga pedig a részvétel tervezésen alapul. Az alkalmazkodóképességi teszt egyik terméke egy kvantitatív eredménytábla, amely jelzőlámpák formájában, vizuálisan jeleníti meg a teszt eredményeit (piros, sárga és zöld) a kulcsterületekhez igazítva (pl.: gyógyszerellátás, infrastruktúra, finanszírozás, humán erőforrás). Az eredménytábla nem a végtermék, hiszen maga a teszt 5 lépésből áll össze, az utolsó lépés az eredmények riportálása, akciótervek megfogalmazása és implementáció [19].

\section{MEGBESZÉLÉS}

Az irodalmak jelentős részének egyik fontos megállapítása az, hogy a jól működő, megfelelő forrásokkal ellátott, jól menedzselt és szervezett egészségügyi rendszerek reziliensebbek. A felkészültség önmagában még nem garantálja az alkalmazkodóképességet, ha a sokk bekövetkezik, a sokkkezelési stratégiák megléte szintén kritikus fontosságú. Ehhez hatékony vezetésre van szükség a kapacitások és az ellátások biztosítása érdekében az összes rendelkezésre álló erőforrás mozgósításához és összehangolásához, ideértve a munkaerő motiválását, a pénzügyi tartalékok felhasználását és a pénzügyi kifizetések fenntartását és egyes esetekben a pénzkifizetések kibővítését, valamint a szolgáltatásnyújtási és beszerzési mechanizmusok egységesítését, átgondolását, továbbá a megbízható információ áramlását a döntéshozók felé $[11,12,13$.] A mostani járványhelyzet, illetve más országok tapasztalatai rámutatnak arra, hogy nagyon fontos felkészülni, válságterveket és ajánlásokat kidolgozni egy-egy potenciális vészhelyzetre pl.: tömegkatasztrófa, kibertámadás, illetve a meglévő terveket is folyamatosan frissíteni és aktualizálni szükséges, valamint érdemes gyakorlatokat, képzéseket szervezni, amelyek segítik a problémamegoldást, döntéshozatalt [2] .Ugyanakkor a rezilienciaképesség túlmutat a hirtelen sokkokra adott válaszokon és magában foglalja a mindennapi alkalmazkodóképességet is, vagyis a krónikus kihívásokra ugyanúgy figyelmet kell fordítani, mert ezek kezelése elősegíti a rezilienciát az akut helyzetben is [14].

A reziliencia nem az önellátást és az önállóságot jelenti. Éppen ellenkezőleg, az alkalmazkodóképes egészségügyi rendszereknek erős külső kapcsolataik vannak a regionális és globális partnerekkel, amelyek lehetővé teszik a kormányok számára, hogy szélesebb körü erőforrások gyors felhasználását kezdeményezzék. Ez az okos függőség (smart dependency) egyik példája. Az egészségügyi rendszer rezilienciája globális közjó, és a közösség kollektív válaszát igényli. Fontos, hogy ne csak nemzeti szintű, hanem globális megoldások is szülessenek (új alapok, donorforrások stb.) $[10,15]$. Erre lehet egy jó példa a COVID-19 járvány idején létrehozott Uniós kezdeményezés a Vészhelyzeti Támogató Eszköz (Emergency Support Instruments) vagy a felállítani tervezett az Egészségügyi Szükséghelyzet-reagálási Hatóság (European Health Emergency Preparedness and Response Authority (HERA)) [16,17].

A szakirodalmak alapján az egészségügyi ellátórendszer rezilienciáját erősítő elemek lehetnek a védett és változatos finanszírozási mechanizmusok/bevételek biztosítása, bevethető tartalékkapacitások és a rendszeresen felülvizsgált kockázatértékelési tervek megléte, egy jól működő epidemiológiai jelzőrendszer, a helyszíni gyakorlati tapasztalatok gyűjtése, a rugalmas rendszertervezés (szocio-technikai szempontok alkalmazása [20]), univerzális lefedettség a szolgáltatásokhoz való hozzáférést illetően, hatékony kommunikáció, motivált munkaerő és átlátható vezetés, elszámoltathatóság [21-24]. Forman és munkatársai kifejezetten a 
COVID-19 járványra vonatkoztatva megerősítették a fenti tulajdonságokat és kiemelték az egészségügyi rendszerek tesztelésének fontosságát. A vírus hirtelen berobbanása több ország egészségügy rendszerét felkészületlenül érte, ezzel egy időben pedig olyan kérdések is előtérbe kerültek, mint a gyógyszerellátottság, védőeszköz-ellátottság bizonytalanságai [25]. Szintén fontos az új kihívásokon alapuló kutatás-fejlesztés, készletgazdálkodás erősítése, a folyamatos harc a dezinformáció ellen, az alapellátás és a mentális ellátások megerősítése, a méltányossági alapú döntéshozatal érdekében a fertőzöttségi adatok elemzése például nem, életkor, társadalmi-gazdasági helyzet, társbetegségek és a tartós gondozási intézményben való tartózkodás szerint [20, 25].

Hazánkban régóta nyomon követhető a korlátozott pénzügyi források és a növekvő ellátási igények diszkrepanciája (ezt mutatják pl.: a várólisták). Ugyanilyen krónikus sokk a humán erőforrás szűkössége, az utánpótlás hiánya, amely évek óta hatással van a rendszer működésére. Akut sokként pedig a COVID-19 jelenléte a meghatározó. Az, hogy a hazai rendszer hogyan tud talpra állni a járványt követően, képes lesz-e a teljesítményét visszahozni a kiindulási állapothoz vagy esetleg alacsonyabb, esetleg magasabb szintet tud-e elérni, a következő időszak nagy kérdése. Azonban a járvány jelenléte reményeink szerint előmozdítja azokat az évek óta tervezett strukturális, infrastrukturális, informatikai és finanszírozási változásokat, amelyek jobban segíthetik az egészségügyi rendszer céljait. A következő időszaknak a tanulásról és a felkészülésről kell szólnia: annak megerősítéséről, amit jól csináltunk, továbbá a gyengeségek azonosításáról és azok fejlesztéséről.

Fontos lenne hazánkban is a monitorozásra nagy hangsúlyt fektetni. Ehhez a régóta tervezett népegészségügyi, szocio-ökonómiai, gazdasági adatok betegrekordokhoz csatolása nagyon hasznos lenne. Továbbá szükség lenne olyan indikátorok kidolgozására, kiválasztására, nyomon követésére, amelyek jól tükrözhetik a teljesítmény alakulását, krónikus vagy akut sokkok esetén: az egészségügyi rendszer rezilienciáját. Ideális egy olyan módszer lenne, amellyel nem csupán észlelni lehetne a teljesítmény csökkenését, hanem előre is lehetne jelezni. A Magyar Egészségügyi Teljesítményértékelési Rendszer (MÉRTÉK) részben szintetizálja a különböző adatbázisokból előállítható indikátorokat, részben pedig ellátási outcome-okat vizsgál, hogy egy általános képet adjon az egészségügyi rendszer működéséről különböző dimenziók mentén [26]. Ennek a szakmai munkának a továbbvitele, fejlesztése nagy segítséget jelenthet a rendszer alkalmazkodóképességének értékeléséhez is.

\section{IRODALOMJEGYZÉK}

[1] Székely I: Resilience: from systems theory to the social sciences [Reziliencia: a rendszerelmélettől a társadalomtudományokig], Replika, 2015/5. szám, 7-23. oldal, Elérhető: (letöltve: 2020. 07. 02.)

[2] EU Expert Group on Health Systems Performance Assessment (HSPA) (2020), Assessing the resilience of health systems in Europe: an overview of the theory, current practice and strategies for improvement, Publications Office of the EU, Luxembourg. (letöltve: 2020. 12. 02.)

[3] Kruk ME, Myers M, Varpilah ST et al.: What is a resilient health system? Lessons from Ebola. The Lancet, 385(9980), 1910-1912., 2015, https://doi.org/10.1016/S0140-6736(15)60755-3 (letöltve: 2020. 12. 02.)

[4] Joint Research Centre (JRC) - The resilience of EU Member States to the financial and economic crisis What are the characteristics of resilient behaviour? 2018, doi:10.2760/840532, (letöltve: 2020. 12. 02.)

[5] Joint Research Centre (JRC) - Building a scientific narrative towards a more resilient eu society, part 1: a conceptual framework., 2018 Retrieved from, (letöltve: 2020. 12. 02.)

[6] Blanchet K, Nam SL, Ramalingam B et al.: Governance and Capacity to Manage Resilience of Health Systems: Towards a New Conceptual Framework. Int J Health Policy Manag. 2017;6(8):431-435. Published 2017 Aug 1. https://doi.org/10.15171/ijhpm.2017.36 (letöltve: 2020. 12. 02.)
[7] Expert Panel on effective ways of investing in health (EXPH), The organisation of resilient health and social care following the COVID-19 pandemic, 25 November 2020, (letöltve: 2020. 12. 02.)

[8] Hanefeld J, Mayhew S, Legido-Quigley H. et al.: Towards an understanding of resilience: responding to health systems shocks. Health Policy Plan, 33(3), 355-367., 2018 https://doi.org/10.1093/heapol/czx183, (letöltve: 2020. 12. 02.)

[9] Maresso A, Wismar M, Greer S et al.: What makes health systems resilient and innovative? voices from Europe, Eurohealth, Euro Observer - Vol.19, No.3, 2013, 3-6 p., (letöltve: 2020. 12. 02.)

[10] Fridell M, Edwin S, von Schreeb J et al.: Health System Resilience: What Are We Talking About? A Scoping Review Mapping Characteristics and Keywords. International Journal of Health Policy and Management, 9(1), 6-16., 2019 https://doi.org/10.15171/ijhpm.2019.71

[11] Barasa E, Mbau R, Gilson L: What Is Resilience and How Can It Be Nurtured? A Systematic Review of Empirical Literature on Organizational Resilience. International Journal of Health Policy and Management, 7(6), 491-503.,2018, https://doi.org/10.15171/ijhpm.2018.06, (letöltve: 2020. 12. 02.)

[12] Thomas S, Sagan A, Larkin J. et al.: Strengthening health systems resilience: key concepts and strategies, 2020, (letöltve: 2020. 12. 02.) 
[13] Kutzin J, Sparkes SP: Health systems strengthening, universal health coverage, health security and resilience. Bulletin of the World Health Organization, 94(1),2016 22. https://doi.org/10.2471/BLT.15.165050

[14] Barasa E, Cloete K, Gilson L: From bouncing back, to nurturing emergence: reframing the concept of resilience in health systems strengthening. Health Policy Plan, 32(suppl_3), iii91-iii94., 2017. https://doi.org/10.1093/heapol/czx118

[15] OECD/European Union (2020), Health at a Glance: Europe 2020: State of Health in the EU Cycle, OECD Publishing, Paris. https://doi.org/10.1787/82129230-en (letöltve: 2020. 12. 02.)

[16] Emergency Support Instruments: (felkeresve: 2021. 02. 10.)

[17] Az Egészségügyi Szükséghelyzet-reagálási Hatóság (HERA): (felkeresve: 2021. 03. 12.)

[18] Hanefeld J, Mayhew S, Legido-Quigley H et al.: Towards an understanding of resilience: responding to health systems shocks. Health Policy Plan, 33(3), 355-367., 2018, https://doi.org/10.1093/heapol/czx183, (letöltve: 2020. 12. 02.)

[20] Expert Panel on effective ways of investing in health (EXPH), The organisation of resilient health and social care following the COVID-19 pandemic, 25 November 2020, (letöltve: 2020. 12. 02.)
[21] Rosso CB, Saurin TA: The joint use of resilience engineering and lean production for work system design: $A$ study in healthcare. Appl Ergon. 2018; 71:45-56. https://doi.org/10.1016/j.apergo.2018.04.004, (letöltve: 2020. 12. 02.)

[22] Iflaifel M, Lim RH, Ryan K et al.: Resilient Health Care: a systematic review of conceptualisations, study methods and factors that develop resilience. BMC Health Services Research, 20, 1-21., 2020, https://doi.org/10.1186/s12913-020-05208-3, (letöltve: 2020. 12. 02.)

[23] Thomas S, Sagan A, Larkin J, Cylu J et al. (2020), European Observatory on Health Systems and Policies): Strengthening health systems resilience: key concepts and strategies. World Health Organization. Regional Office for Europe, (letöltve: 2020. 12. 02.)

[24] Forman R, Rifat A, McKee $M$ et al.: 12 lessons learned from the management of the coronavirus pandemic. Health Policy, 2020, https://doi.org/10.1016/j.healthpol.2020.05.008, (letöltve: 2020. 12. 02.)

[25] https://www.consilium.europa.eu/hu/policies/coronavirus/ fighting-disinformation/

[26] MÉRTÉK - Magyar Egészségügyi Rendszer Teljesítményértékelése, elérhető: https://mertek.aeek.hu/

\section{A SZERZŐK BEMUTATÁSA}

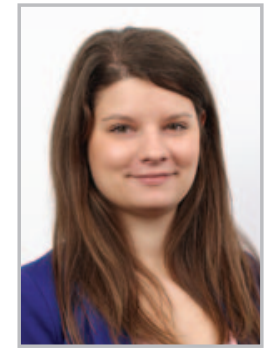

Farkas Borbás Fanni 2012-ben diplomázott az Eötvös Loránd Tudományegyetem Egészségpolitika tervezés és finanszírozás mesterképzésén. 20112014 között a GYEMSZI Egészségszervezési és Finanszírozási Főigazgatóságán dolgozott. 2015-től az Állami Egészségügyi Ellátó Központ Központi

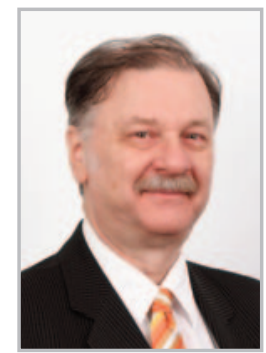

Dr. Gresz Miklós 1981-ben szerzett általános orvosi diplomát. 1985-ben általános sebészi, 2005-ben egészségbiztosítási szakvizsgát tett. 2000-ben a Budapesti Közgazdasági Egyetemen okleveles orvos-közgazdász diplomát szerzett. 1981-90-ig általános sebészeten, 1990-2001-ig az Országos Mentőszolgálat Kórháza Traumatológiai osz-
Adattárház és Elemzési Főosztályán, majd a Szolgáltatásfejlesztési Igazgatóságon, jelenleg pedig az Országos Kórházi Főigazgatóság Szolgáltatástervezési és Módszertani Osztályán dolgozik. 2019-ben abszolutóriumot szerzett az ELTE Szociálpolitika PhD programjában. Kutatási témája a szociális és egészségügyi ellátórendszer közötti kapcsolat és az együttműködési lehetőségek vizsgálata a krónikus betegségek ellátása és a hosszú idejű ápolás területén.

tályán, 2001-2011-ig az Országos Egészségbiztosítási Pénztár Finanszírozási Főosztályán dolgozott. A GYEMSZIbe 2011-ben vették fel. Jelenleg az Országos Kórházi Főigazgatóságon áll alkalmazásban. 2008 óta részt vesz a szakorvosképzésben, 2016 óta az orvos-jogász képzésben is. Munkája során a finanszírozási rendszer, és az egészségügy működésének elemzésével foglalkozik, mely témákban több előadást tartott, cikkei jelentek meg.

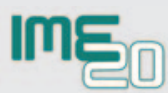

\section{IME Országos Egészség-gazdaságtani Továbbképzés és Konferencia \\ 2021.09.02. \\ Orvosok és gyógyszerészek részére kreditpontszerző!}

